\title{
THE WHITE STORK IN PORTUGAL
}

\author{
By Dr. J. R. Dos SAntos Junior
}

Both the black stork (Ciconia nigra) and the white stork (Ciconia ciconia) are found in Portugal. The black stork is much the rarer and more local, being found in steep, hot places in the eastern and north-eastern provinces.

The white stork is quite common, especially in the south of the country-the provinces of Alentejo and Estremadura. During springploughing a few years ago eighty to ninety birds were seen feeding close to the farmworkers at Golegã. By the rivers Tagus, Sado, and Guadiana they are common. In the north of Portugal they nest in the fields of the Mondego, a few near Aveiro, and fairly abundantly in the eastern parts of the country.

The stork enjoys an especial esteem among the people and is rarely molested. At Figueira de Castelo Rodrigo when a nest on a church was destroyed by a storm, the local people put up an iron framework and replaced the nesting material. Each year the nest is repaired by the local Council, and the storks return. Many traditional beliefs exist in connection with the stork, which is held in great respect by most of the country people. At Abrantes it is called "The Queen of the Rice Fields". At Miranda do Douro in the extreme north-east, it is said of a very restless person "He must have killed a stork", expressing the idea of a curse falling on someone who kills this bird. In the same district there is a saying that if one destroys a stork's nest, the crops of wheat and rye will be beaten down by hailstorms that season. Formerly to kill a stork was a crime punishable by the cutting off of a hand.

The stork is expected to return, in this north-eastern region, around the day of S. Bras (3rd February), but if it is late arriving it is a sign of a bad year for agriculture.

Among popular sayings are the following :-

"In early July, the storks start to fly."

"Storks do not choose the elms of the Jews."

"Storks nest in the trees of fortunate people."

"Storks will only nest where there is a Church with the Holy Sacrament."

In the province of Beira Baixa the arrival of the storks was an occasion for joy, and one said to another "Here comes the stork with 20 cents in its bill ". A curious old verse survived until fairly recently. The storks were greeted with :-

Stork, go to Porto,

There you'll find

Your dead father.

Eat his flesh,

And leave the bones

For breakfast. 
Can this refer to cannibalistic propensities among storks ? $R$. Thévenin writes of seeing excited gatherings of storks in August. In contrast to their usual quiet behaviour, he saw what seemed to be an argument and some birds setting upon their companions and massacring them.

Thanks to grants from the Gulbenkian Foundation the author was able to travel over much of the country by car to collect information, but he could not cover the whole country or investigate every nest. He prepared a simple questionnaire which was sent to the local authorities for distribution among the parishes. This asked for the number of storks' nests in the parish, the site of the nests, and if possible the number of young in each nest. Replies were in general satisfactory. With this information, his own observations and valuable help from Dr. Agostinho Isidoro and Sr. Antonio de Jesus Pereira, he made a distribution map of the stork in Portugal.

The density of the stork population naturally depends on the availability of habitats preferred by the stork. It avoids mountains and prefers wide plains with few trees. This sort of country is found in the Alentejo which is the province with the highest stork density, along with the plateau of Mogadouro and Miranda in the north-east. The stork is most abundant in the south. In the north there is a belt along the frontier with Spain. In the extensively flooded area near Aveiro which would seem to be very suitable, there are very few nests. While fish and amphibians, especially frogs, are favourite foods of adult storks, it seems that grasshoppers, molluscs and snails are most suitable for the young birds, especially in the earliest days. This might explain the scarcity of nests at Aveiro.

The total of nests registered in 1958 and part 1959 was 3,471. The district of Golegã in the province of Ribatejo had the highest density with fifty-three nests to $70.8 \mathrm{sq}$. kilometres, an average of 74.6 nests to 100 sq. kilometres.

The nesting sites chosen were in the following order of preference :-

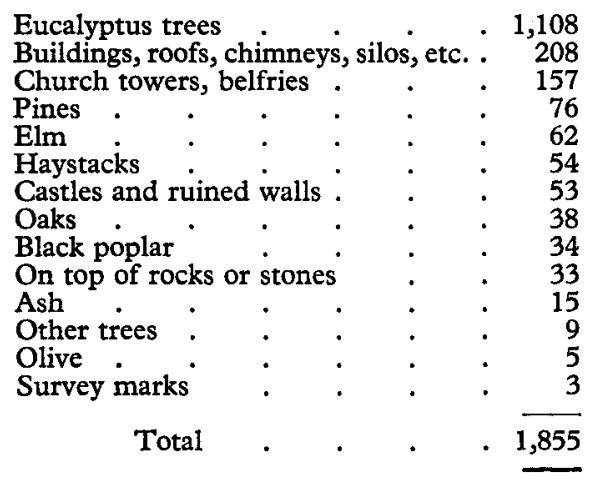

Of the 1,855 nests investigated, out of a total for Portugal of 3,471 , 1,347 were in trees, eucalyptus being by far the most common. In Alentejo province huge stacks of straw 8 to 10 metres high are common. 
One nest was on a rock surrounded by the sea, and a few other nests in similar sites were reported.

It is quite usual to find one young stork dead below the nest. Local people have traditional stories to account for this. The real reason, however, seems to be in the laying habits of the stork. The hen lays on alternate days, but starts incubating with the first egg. Thus the last chick to hatch must be much smaller and weaker than the others. The following table was compiled from 459 nests in which it was possible to count the number of young :-

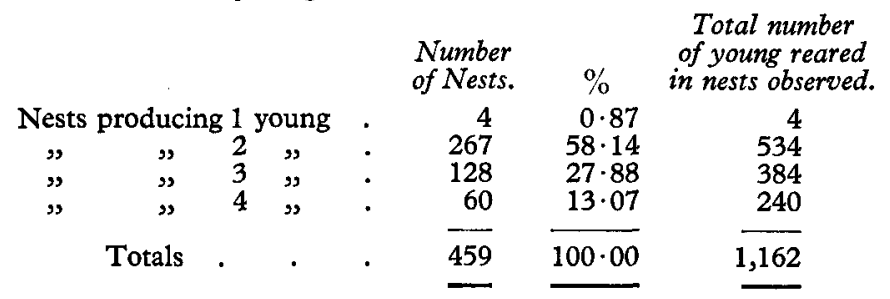

This calculation results in an average of 2.5 young per nest over the whole country. There was actually a higher breeding rate in the south with 3.8 per nest as against 2.3 per nest in Vimioso in the north.

Some pairs seem to be territorial while others are gregarious. In Varge the pair of storks in residence fiercely attacked a second pair which attempted to nest by the same stream bed, and finally drove them away. At Fonte de Aldeia several elms in a meadow afforded good nesting sites, but the pair in occupation chased off all other storks attempting to build in that meadow. By contrast in many places colonies of ten, twenty or more nests exist, often side by side. Eleven nests were seen in one eucalyptus and seven in a neighbouring one. In November, 1960, the author counted seventeen nests in one eucalyptus, only one of which seemed to be an old one.

It is difficult to say definitely whether there are as many white storks in Portugal as there were twenty or thirty years ago, but there seems to have been little alteration in either their number or their distribution.

Note : Dr. Santos Junior is Professor of Zoology at the University of Oporto. His full report with a distribution map is entitled "Demografia da Cegonha Branca em Portugal ", and is published by Imprensa Portuguesa, 108 Rua Formosa, 116 Oporto.

The article is translated from the Portuguese by A. M. V. Boyle. 